\title{
24
}

\section{A Modeling Framework and Preliminary Results in Assessing Phnom Penh's Sewage Discharges}

\author{
M. Kummu, T. Sokvongsa, J. Sarkkula, J. Koponen, \\ O. Kagna, L. Moniphea, U. Mengieng, M. Sampson, \\ K.N. Irvine, S.J. Vermette, T. Tang, and M. Keskinen
}

\subsection{Introduction}

The 2002 World Summit on Sustainable Development (WSSD) recognized that water and sanitation are vital to protect human health and promote sustainable human settlements. The WSSD identified the goal of halving, by the year 2015, the proportion of people worldwide who are unable to reach or to afford safe drinking water or have access to basic sanitation. These goals also were in keeping with the Millennium Development Goals set by the United Nations in 2000. In Cambodia, mortality due to waterborne disease is high, in part reflecting the fact that less than $10 \%$ of the rural population and $55 \%$ of the urban population has access to adequate sanitation (Irvine et al., 2006).

Globally, constructed wetlands are gaining acceptance as an effective, low cost, and sustainable alternative to sewage treatment (Campbell and Ogden, 1999; U.S. EPA, 2000; UNEP, 2004). The UNEP (2004) noted that the advantages of wetlands treatment includes utilization of solar energy to

Kummu, M., T. Sokvongsa, J. Sarkkula, J. Koponen, O. Kagna, L. Moniphea, U. Mengieng, M. Sampson, K. Irvine, S. Vermette, T. Tang and M. Keshinen. 2007. "A Modeling Framework and Preliminary Results in Assessing Phnom Penh's Sewage Discharges." Journal of Water Management Modeling R227-24. doi: 10.14796/JWMM.R227-24.

(C) CHI 2007 www.chijournal.org ISSN: 2292-6062 (Formerly in Contemporary Modeling of Urban Water Systems. ISBN: 0-9736716-3-7) 
drive purification processes; longevity of a large system (50-100 years); selfsustaining; effective removal of sediment, pathogens, nutrients, and metals from the wastestream (when properly designed); relatively low cost; low tech maintenance; possiblility of accruing economic benefits from plant harvesting and fishing in some cases. However, Kivaisi (2001) argued that the rate of adoption of wetlands technology for wastewater treatment in developing countries (particularly those in the tropics) has been slower than it should be, in part because donor countries favor technologies that have commercial spin-offs, and in part because technical advisors from developed countries have a tendency to translocate conventional treatment approaches (e.g. secondary or tertiary centralized treatment plants) from their countries rather than adjusting to the realities and cultures of developing nations.

Increasingly, there are studies that have documented the treatment efficiency of a properly designed and maintained wetland. For example, the U.S. EPA (2000) reported reductions in suspended solids concentrations of up to $86 \%$ for surface flow wetlands, while $\mathrm{BOD}_{5}$ concentration was reduced by up to $96 \%$. Hiley (1995) reported similar removal rates for BOD and suspended solids. Kootatep et al. (2005) showed reductions in the range of $80-96 \%$ for COD, suspended solids, and TKN in test studies of constructed wetlands in Thailand. Nelson et al. (2004) found that wetlands reduced copper and mercury by $80 \%$, lead by $83 \%$, and zinc by $60 \%$ from industrial process wastewater and stormwater. Walker and Hurl (2002) found wetlands reduced zinc, lead, and copper, principally through sedimentation, but chromium concentrations remained the same and arsenic levels increased. Results for chromium and arsenic may have been related to their chemical behavior and the role of organic matter in the wetland. Quinonez-Diaz et al. (2001) reported that $90 \%$ of all indicator microorganisms (total and fecal coliform, coliphages, Giardia, and Cryptosporidium) were removed from domestic wastewater by their test wetland. Kivaisi (2001) summarized removal efficiency data from a number of developing countries and reported nitrogen was reduced by $30-50 \%$, phosphorus by $20-60 \%$, and indicator bacteria by $60-99 \%$. The forms of the nitrogen and phosphorus were not provided.

The city of Phnom Penh, Cambodia (population 1.3 million) is serviced by a combined sewer system that drains stormwater runoff as well as municipal and industrial discharges. The city does not have a wastewater treatment plant, but most domestic sanitary flow and stormwater runoff is discharged to a system of wetlands located around the city for treatment. Ultimately, these discharges reach the Tonle Sap/Bassac/Mekong River system, hereafter referred to as the Chaktomuk confluence. The Chaktomuk 
confluence is where the Mekong main stream divides into two branches, the Mekong and the Bassac River, and where the Tonle Sap River drains into the above branches (Figure 24.1). The Mekong River is one of the major rivers of the world, extending approximately $4,800 \mathrm{~km}$ from the Tibetan Plateau to the South China Sea and having a drainage area of $795,000 \mathrm{~km}^{2}$. Mean annual flow (1960-2004) for the river at Kratie is $13,200 \mathrm{~m}^{3} \mathrm{~s}^{-1}$, but during peak rainy season (September), monthly mean flow (1960-2004) is $36,700 \mathrm{~m}^{3} \mathrm{~s}^{-1}$ (Mekong River Commission (MRC), 2005).

The Tonle Sap/Mekong/Bassac River system is one of the most productive and biodiverse (in terms of species richness) inland fisheries in the world (Dudgeon, 2000; MRC, 2003). It also is an important water source for irrigation and drinking water and there is increasing pressure for hydropower development (MRC, 2001). It is essential that this important river system not become degraded due to urban waste discharge. The Tonle Sap River reverses its flow annually when the Mekong flood starts rising in May-June due to the monsoon rains and snowmelt from Tibet. The Mekong waters flow to the Tonle Sap Lake for about four months, extending its size from the basic $2,500 \mathrm{~km}^{2}$ to $15,000 \mathrm{~km}^{2}$ during high flood years (Fuji et al., 2003; MRC/WUP-FIN, 2006). The lake depth increases from about 1 meter in dry season up to 10 meters during peak flood. The turning of the flow direction also means that the wastewater impacts from Phnom Penh are divided periodically between downstream Mekong and Bassac and 'upstream' Tonle Sap River and lake.

The objectives of this chapter are twofold. First, preliminary sample results from Phnom Penh's sewer system, wetlands treatment system, and receiving waters are presented to provide some understanding about treatment efficiency and impact on the receiving waters. Second, a modeling framework is described, together with some preliminary test runs, to begin examining contaminant fate in the Chatkomuk confluence. The modeling work presented below is part of the work done within the Mekong River Commission Secretariat (MRCS) Project WUP-FIN, which is a complementary, Finnish government funded component to the MRCS Water Utilization Programme (MRC/WUP-FIN, 2005). The objective of the WUPFIN Project is to develop analytical tools for hydrological, environmental and socio-economic impact assessment in the Lower Mekong Basin (LMB) (e.g. Koponen et al. 2005; Keskinen et al., 2005). An important part of the work is to assess the possible transboundary impacts of basin developments and facilitate the related discussions between the member countries. The Phnom Penh wastewater impacts fall into this category due to their transport further down to the Vietnam part of the Mekong delta. The MRC has been 
established to provide a constitutional framework for the member country negotiations. The MRC member countries are Cambodia, Laos, Thailand and Vietnam. The other Mekong Basin countries, China and Myanmar are official dialogue partners to the MRC. Capacity building is one of the key components of the WUP-FIN Project which necessitates close cooperation with national institutions, line agencies, and universities. International cooperation in these questions, like the one described in this chapter, are of great help to magnify the effects of single efforts by their synergies and shared motivations.

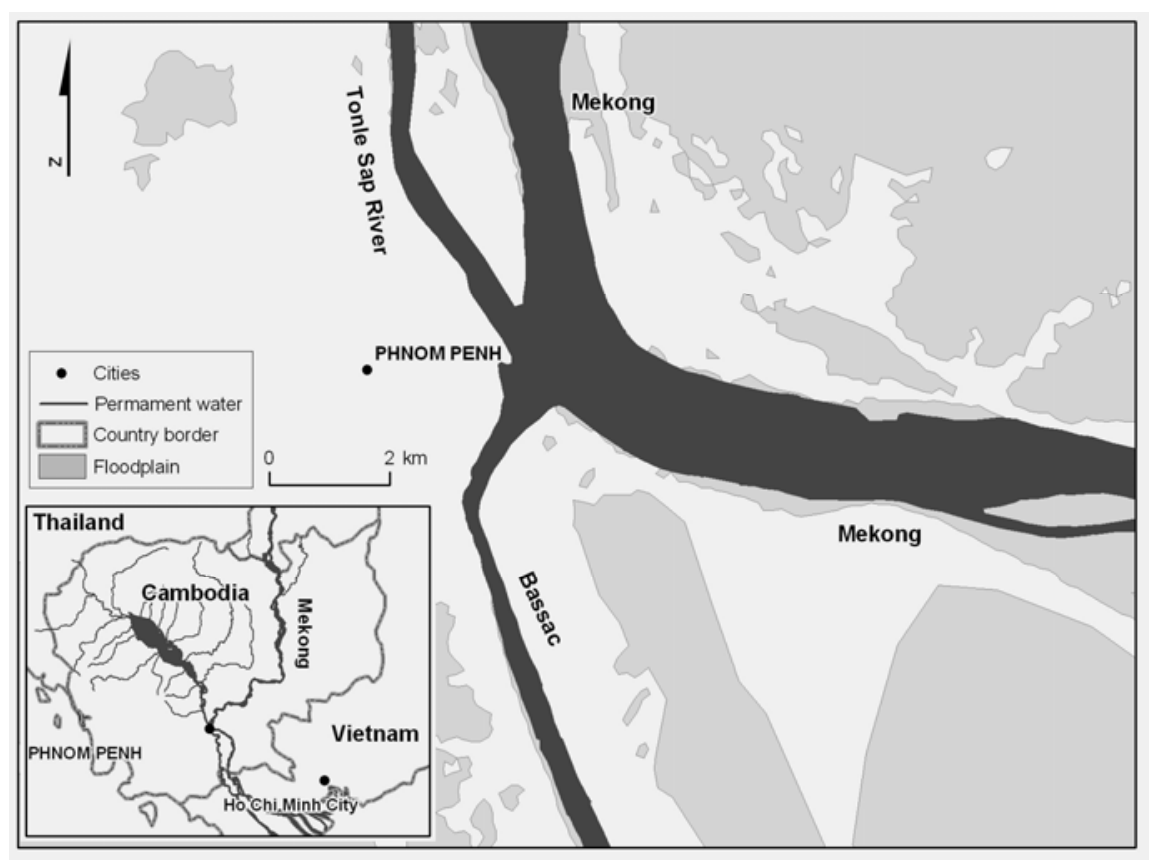

Figure 24.1 Chaktomuk confluence.

\subsection{MRC Institutional Framework}

In the Mekong River Basin an international water management regime has existed since 1957. The Mekong regime has a constitutional framework that sets out general principles and procedures and organizational structure. The 
Mekong regime has evolved over three distinct periods, each with its own constitutional structure (Browder and Ortolano, 2000)

- the Mekong Committee era (1957-1975)

- the Interim Mekong Committee era (1976-1995), and

- the Mekong River Commission era (1995-present).

The Mekong Committee and Mekong Interim Committee era were characterized by ideological and military struggle and geopolitical changes in the region. The Mekong regime survived thanks to the neutral sponsorship of the United Nations Development Programme (UNDP) and donor assistance. European donors, especially the Nordic countries, became the main benefactors to the Mekong regime.

The three primary dimensions of the Mekong regime - water management, regional geopolitics, and international development assistanceconverged in the early 1990s in ways that created the need for a new constitutional framework. In 1995, the governments of Cambodia, Laos, Thailand, and Vietnam signed the "Agreement on the Cooperation for the Sustainable Development of the Mekong River Basin." The 1995 Mekong Agreement established a new organization, the Mekong River Commission (MRC), and led to the third era of the Mekong regime, composed of the political and negotiating bodies, the Council and the Joint Committee, and the Secretariat composed of riparian and international staff. The primary functions of the MRC Secretariat are to procure international assistance, administer projects, and undertake selected technical tasks such as maintaining information decision support systems. e.g. databases and models.

\subsection{Impact Assessment Needs}

However obvious the needs for an integrated and cooperative approach for impact assessment in shared water basins are, there seems to be still a long way to go; some progress in integration of the teams from natural and engineering sciences has been made, but progress in integrating these quantitative approaches with the social sciences and data has been slower. Issues of meaningful stakeholder (or civil society) input, appropriate transfer of experience from developed to developing countries, and institutional arrangements also present challenges to water resources management (Miller and Hirsch, 2003). The systematic consideration of environmental science and socio-economics for natural resource management decision-making can 
be traced back at least to works such as The Limits to Growth (Meadows et al., 1972) and Mankind at the Turning Point (Mesarovic and Pestel, 1974). However, Roughley and Salt (2005) have noted that Natural resource management issues have long been viewed as predominantly biophysical in nature. The introduction of social scientists, particularly behavioural scientists working from a constructivist perspective and sometimes using a qualitative methodology, has not always been easy. There are some recent examples of integration between the sciences and social sciences (e.g. Keskinen et al., 2005; Islam, 2005) and this has been facilitated through the use of GIS technology (e.g. Geoghegan et al., 1997; Dai et al., 2004; Sioh et al., 2005), but the approach of modelers has typically been "to add some social stuff" to their models (Nancarrow, 2005).

Successful implementation of water modeling requires thorough understanding of water, environment, and their linkages with the surrounding society. Consequently, modeling should take into account several different fields from environment to economy and society. Information needed in comprehensive water modeling comprises not only hydrological but also environmental, social, economic, and possibly even political and institutional information. Data collection and analysis under the differing paradigms of these wide-ranging disciplines is an enormous challenge, but successful integration of the different types of information presents an even greater challenge. It requires open and long-term cooperation between researchers from different disciplines, preferably as a multidisciplinary team working together from the early, conceptual stages of the project. Sarkkula et al. (2007) and Keskinen (2006) provide examples of this type of integrated approach and cooperation.

As highlighted by Sarkkula et al. (2007), there is still a long way to go to achieve a truly integrated approach for water modeling. While some progress in integration of teams from natural and engineering sciences has been made, the integration with the social sciences remains weak. Real change may come through establishment of teams for integrated assessment and modeling with balanced and equal participation by modelers, natural scientists, social scientists, policy experts and other non-modelers. This can help to formulate the right questions to guide model development in order to come up with the most relevant solutions to address societal issues.

Maybe Janssen and Goldsworthy (1996) flag the way ahead when discussing the importance of multidisciplinary research for natural resources management and the attributes required for successful multidisciplinary efforts and stating that attitude, communication skills, education, and experience are all important attributes. Ultimately, in the work on the 
Mekong River, it is our goal to achieve true integration of the sciences and social sciences in modeling and development of decision-making tools. This chapter represents an early step towards this goal by focusing on a water quality modeling and assessment framework that will be further developed as an integrated decision support system to promote sustainable development in the Mekong Basin.

\subsection{EIA Model Description}

\subsubsection{Core Model Engine}

The core engine of the modeling work is based on the 3-dimensional (3D) EIA Hydrodynamic Model and 3D EIA Water Quality Model (e.g. Koponen et al., 2005). The flow model can be classified as a 3-dimensional baroclinic z-level model and is based on the standard Navier-Stokes equations in a rectangular grid (Koponen et al., 2005). Reasonable simulation times are reached by using appropriate algorithms (e.g. time splitting and implicit solvers) and model resolutions. The model also has a geographic information system (GIS) user interface. The 3D EIA Water Quality Model has been coupled with the flow model for simulating the transport and processes of a selected set of water quality indicators and hazardous materials.

The modeling system uses rectangular grid cells. The cell width can vary in $\mathrm{x}$ - and $\mathrm{y}$-directions. It is possible to model whole domains with varying grid resolutions and couple them together in a nested way.

\subsubsection{1/2/3 Dimensional River Channel Modeling}

Traditionally, the river channel models have been 1-dimensional (1D) especially for large river stretches. For restricted stretches such as critical junctions, erosion zones, coastal areas, floodplains, and where the river channel is wide, 2D and lately 3D models have been devised. Here the 1D, $2 \mathrm{D}$, and 3D approaches are combined into a flexible system where any reach of the river can be modeled in any dimensionality and combined with a model of other dimensionality. The change of the dimensionality is made to be automatic. For instance, there may be local erosion or water quality concern necessitating switching from $1 \mathrm{D}$ to $3 \mathrm{D}$ and this should be accomplished without major work in generating the grid, data input, and reconstructing the model. 


\subsection{The Phnom Penh Collection and Sewage Treatment System}

The city of Phnom Penh is growing by $4 \%$ annually and with a population of approximately 1.3 million people, houses almost half the Cambodian urban population (Heinonen, in press). The city has become a focal point of ruralurban migration due to improved economic opportunities, but Molyvann (2003) notes that the growth has been haphazard and the environmental implications of urban expansion have not been studied in detail. The population living in informal settlements without adequate housing or basic services has increased, particularly in the peripheral districts of the city. In addition to rural-urban migration, part of this increased, under-served population resulted from squatter re-settlement out of the city center (Heinonen, in press).

Within the city center, domestic waste principally is pre-treated via septic tanks that subsequently discharge to the sewer system, while in the outlying districts sanitation options may be limited to use of public toilets, open pits shared by multiple families, or disposal directly to waterbodies, open fields, or plastic bags (Heinonen, in press). JICA (1999) reported that most industries do not pre-treat their effluent prior to discharge to the sewer system. The sewer system, most of which was constructed in the 1960s, consists of underground (mainly circular, concrete) pipes with diameters ranging from 0.3 to $1.5 \mathrm{~m}$ (Phyrun, 1996; JICA, 1999). Because of the large number of unpaved roads within the city and irregular invert slopes, eroded material tends to clog the sewer pipes such that flow capacity frequently is reduced by between 50 and $90 \%$ of design. The number of paved roads within the city has increased dramatically in the past six years and this may reduce the siltation problem. The smaller, underground, concrete sewer pipes discharge to open channels running within the city and the channels ultimately are connected to the sewage treatment wetlands via pumping stations. The open channels vary in size from 2-3 m widths (Tuol Kork and Salang Channels in the north part of the city) to $30 \mathrm{~m}$ widths (Meanchey Channel in the south part of the city). Because of its low elevation and proximity to the Tonle Sap/Mekong/Bassac system, the city is susceptible to flooding and therefore is surrounded by two ring dikes. The pump stations, constructed between 1960 and 1970, help to move the stormwater from the open sewer channels to the treatment wetlands (Boengs) to reduce flooding from within the city. 
Muong (2004) estimated that on a daily basis, $55,600 \mathrm{~m}^{3}$ of domestic waste discharges to the wetlands south of the city (Figure 24.2; see also Irvine et al., 2006). A $30 \mathrm{~mm}$ storm of 24 hour duration also was estimated to discharge nearly 1 million $\mathrm{m}^{3}$ of stormwater flow to these wetlands. The discharge of untreated industrial effluent to the wetlands south of the city is a concern. Muong (2004) noted that based on Ministry of Environment records, 4.6 million $\mathrm{m}^{3}$ of industrial waste annually is discharged to these wetlands from more than 3,000 industrial firms. Industrial activity includes battery repair, paint manufacture, zinc and metal products, pulp and paper, textiles, and plastics production, as well as discharge from a municipal landfill. Local residents actively cultivate aquatic vegetables such as Morning Glory within the wetlands, as well as fish for commercial purposes and there is a concern about metals uptake for these food items (Little et al., 2003; Muong, 2004). However, there has been only limited testing of the wetland soils, vegetation, and fish for metals levels. JICA (1999) sampled sediment at four sites within the wetlands and found the mean level of $\mathrm{Cd}$ to be $1.55 \mathrm{mg} / \mathrm{kg}$ and the mean level of Cr to be $14 \mathrm{mg} / \mathrm{kg}$. More recently, the PAPUSSA (Production in Aquatic Peri-Urban Systems in Southeast Asia) study funded by the European Union has started to report some of its findings. For example, samples of bed sediment in sewage canals discharging to Boeng Cheung Ek (4 sites) had levels of $\mathrm{Pb}$ in the range of $40-120 \mathrm{mg} / \mathrm{kg}$, while a sample site within Boeng Cheung Ek had Pb levels of $<40 \mathrm{mg} / \mathrm{kg}$ and a site near the wetland outlet had levels around $30 \mathrm{mg} / \mathrm{kg}$ (http://www.papussa.org/publications/NIHE-Final\%20Toxic\%20metal\%20 presention.ppt). The higher levels of $\mathrm{Pb}$ in the sewage canals approach the consensus-based probable effect level guideline of $128 \mathrm{mg} / \mathrm{kg}$ recommended by Ingersoll et al. (2000). The PAPUSSA study soon will release a report on metals levels in aquatic vegetation and fish.

The JICA (1999) study collected water samples at six locations in sewers and five locations in treatment wetlands, twice during the dry season and twice during the rainy season. Analytes included fecal coliform, dissolved oxygen, turbidity, conductivity, $\mathrm{pH}, \mathrm{COD}$, and $\mathrm{BOD}$, but metals levels were not reported. Fecal coliform levels in the sewers ranged between 3,600 and $4,600,000$ per $100 \mathrm{~mL}$ and in the wetlands between 21,600 and $4,600,000$ per $100 \mathrm{~mL}$. Dissolved oxygen levels in the sewers ranged between 0.1 and $4.6 \mathrm{mg} / \mathrm{L}$ and in the wetlands between 0.1 and $7.8 \mathrm{mg} / \mathrm{L} . \mathrm{BOD}_{5}$ levels in the sewers ranged between 8 and $76 \mathrm{mg} / \mathrm{L}$ and in the wetlands between 7 and 46 $\mathrm{mg} / \mathrm{L}$. The JICA (1999) data are limited, so it is not possible to draw conclusions regarding the effectiveness of the wetlands in treating the sewage from the study. Under the PAPUSSA study, weekly water samples 
were collected over a 12 week period at two sewage pump stations discharging to the Boeng Cheung Ek wetland and at the outlet of the wetland and analyzed for E. coli and helminth eggs. A 3-4 log reduction in E. coli levels was observed between the input and outlet sites. There was no apparent reduction in the number of samples positive for helminth eggs, but this may have been because of the low number of positive samples at the input sites (http://www.papussa.org/publications/NIHE-Final\%20ww\%20 treatment\%20 capacity.ppt).

Communities (including floating villages) and industries that line the Tonle Sap, Bassac, and Mekong rivers typically discharge waste directly to these receiving waters rather than to the treatment wetlands (Figure 24.3). The Ministry of Environment has mapped 12 major direct discharge points along the Phnom Penh waterfront that receive no treatment (Figure 24.4).

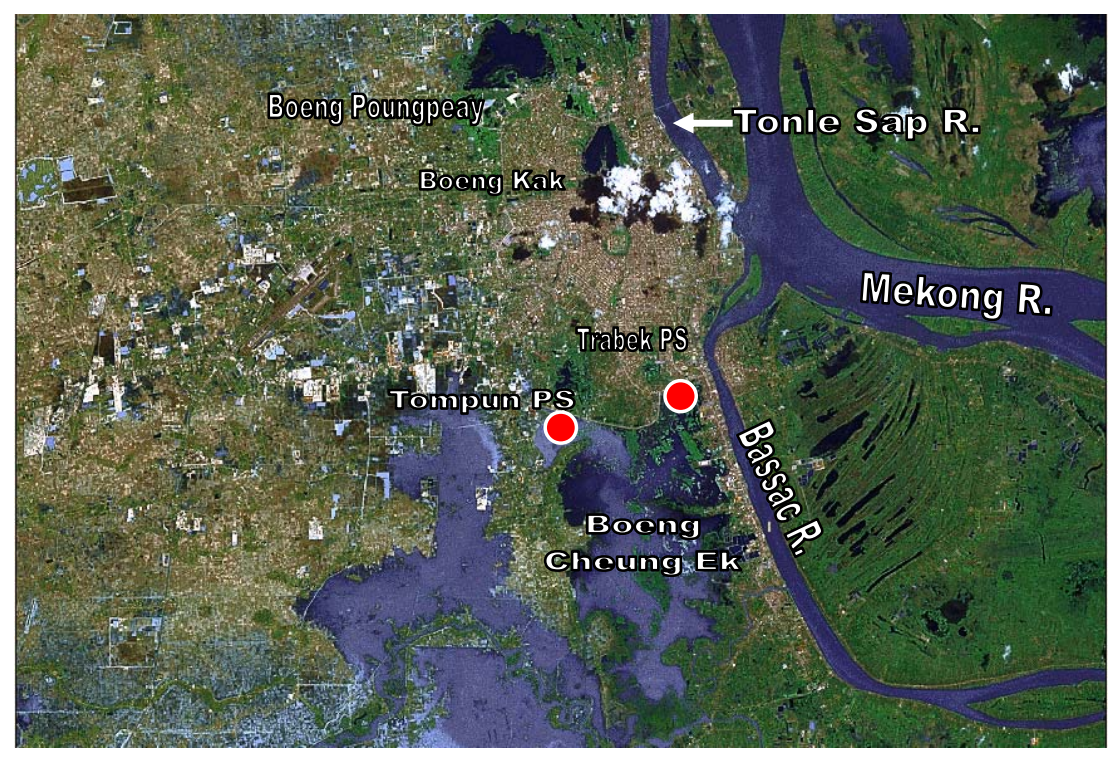

Figure 24.2 Satellite image of Phnom Penh located at the confluence of the Mekong, Tonle Sap, and Bassac Rivers. Also shown are the treatment wetlands (Boengs) and the Tompun and Trabek pump station locations. 

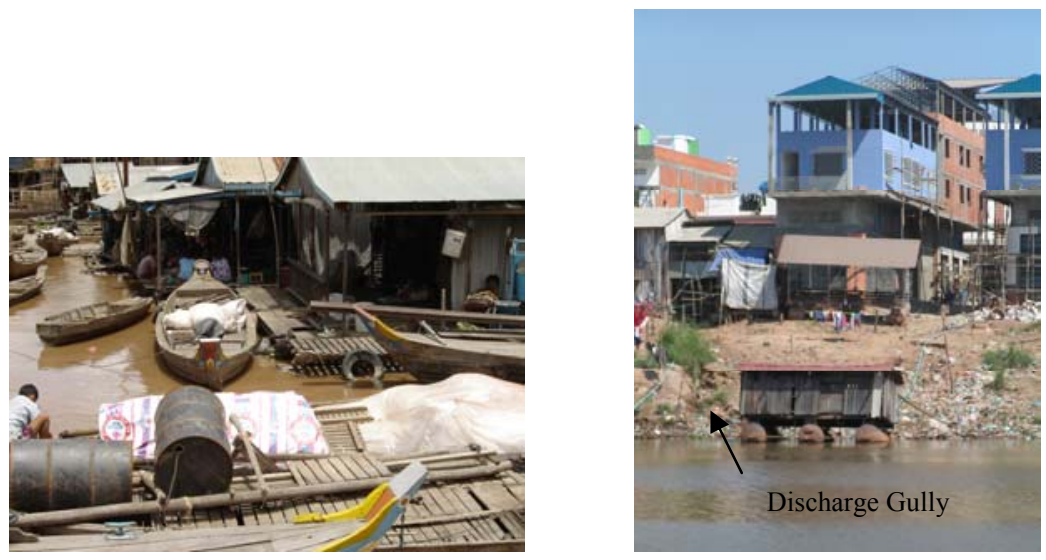

Figure 24.3 Floating houses on the Tonle Sap River (left) and direct residential discharge (right).

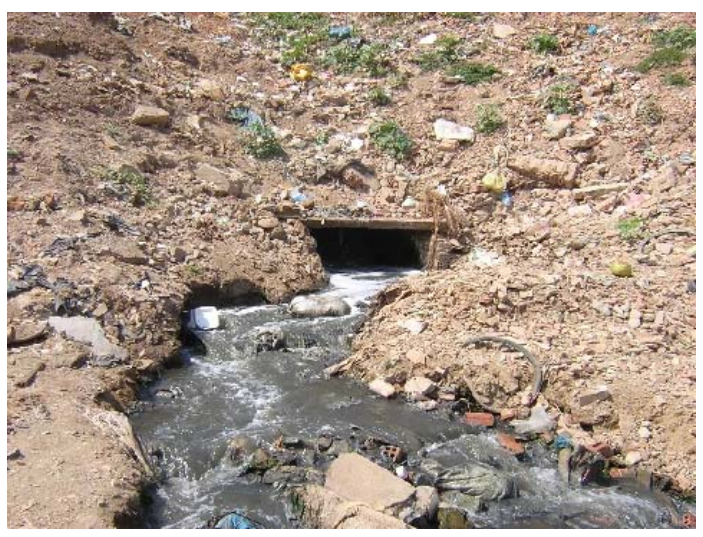

Figure 24.4 Untreated sewage discharge from Phnom Penh. 


\subsection{Sampling and Analytical Methods to Assess Wetland Treatment Efficiency and Receiving Water Impacts}

Three sources of data were available for this preliminary assessment of wetland treatment efficiency and receiving water impacts. The Cambodian Ministry of Environment began routine sampling at four sites on the Tonle Sap/Mekong/Bassac Rivers in 1999 and sampling expanded to nine sites by 2003. Samples are collected once per month at these sites and analyzed for $\mathrm{pH}$, conductivity, dissolved oxygen, $\mathrm{BOD}_{5}, \mathrm{COD}, \mathrm{TSS}$, nitrate/nitrite, phosphate, and fecal coliform (or more recently, total coliform). In this chapter we focus on the data from three sites, Trabek pump station (also shown as BSC site 1), Stung Chrao, and Takhmao (Figure 24.5).

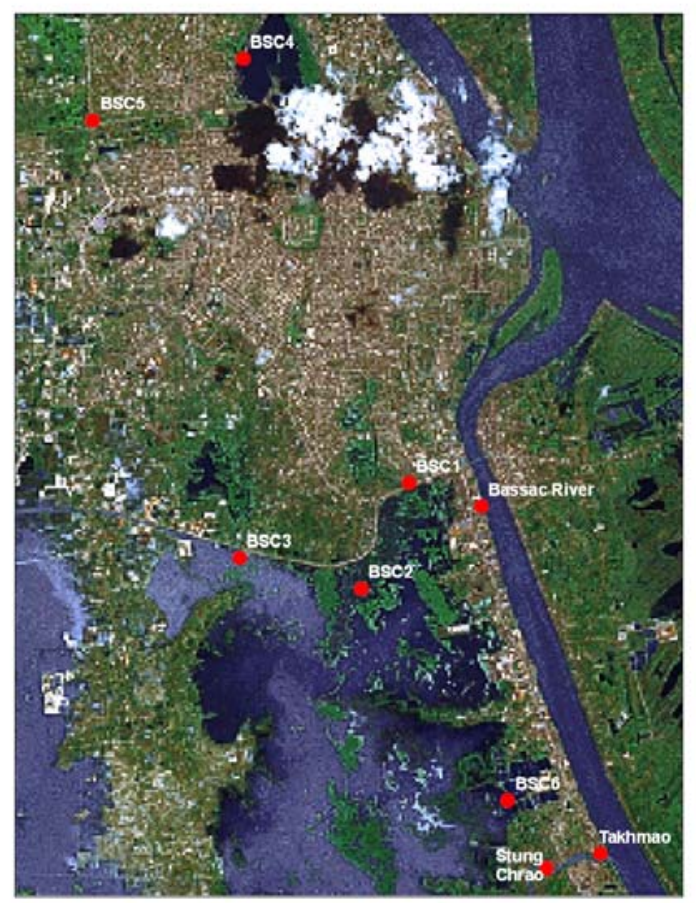

Figure 24.5 BSC and Ministry of Environment sample sites. 
A field team from Buffalo State, Resource Development International Cambodia (RDIC), and Ministry of Environment sampled the sewer system and treatment wetlands twice in 2005. The first sampling was conducted between July 28 and August 4 and represented the early rainy season. The second sampling was conducted on November 15, and represented the early dry season. The first sample date included six sites throughout the city (Figure 24.5; Table 24.1) and the Bassac River at the Hydrolab site (discussed below). The second sample date focused on the southern treatment wetlands only, sites $\mathrm{BSC} 1,3$, and 6. Samples were analyzed for $\mathrm{pH}$, conductivity, dissolved oxygen, total suspended solids (TSS), nitrate, phosphate, arsenic (November only), detergents, and E. coli. The $\mathrm{pH}$, conductivity, and dissolved oxygen were measured with a YSI 556 multisensor system; the TSS was analyzed gravimetrically according to Standard Methods (APHA, 1985); the nitrate was analyzed with a CHEMetrics test kit following the cadmium reduction/azo dye formation method; the phosphate was analyzed using a CHEMetrics test kit following the molybdenum blue/stannous chloride method; detergents (anionic surfactants) were determined with a CHEMetrics test kit following the methylene blue method; arsenic was analyzed using a Hach 5-reagent kit; E. coli levels were determined using Coliscan Easygel media and plates.

It must be recognized that lab facilities in Cambodia are very basic and the analytical approaches used in this preliminary study reflected these conditions. However, the kits used in the analyses have been evaluated for accuracy and robustness through Buffalo State's Aquanauts Program (http://buffalostate.edu/orgs/aqua/) that has trained hundreds of Western New York high school students and teachers in water quality evaluations. Citizen's groups throughout the U.S. successfully have used the Coliscan Easygel system in monitoring programs (e.g. Alabama Water Watch (1999); Virginia Citizen Water Quality Monitoring Program (2003); Texas Watch (http://www.texaswatch.geo.txstate.edu/Newsletters/98-04.pdf); Hoosier Riverwatch (http://www.in.gov/dnr//riverwatch/pdf/manual/Chap4.pdf); Alliance for the Cheasapeake Bay Citizens Monitor (http://www.acbonline.org/pubs/projects/deliverables-87-1-2003.pdf); University of Vermont (2003)) and we have used the system for workshops in Cambodia and research projects in Thailand (e.g. Irvine et al., 2006; Krueger et al., 2005; Gugino et al., 2006). The Virginia Department of Environmental Quality approved the Coliscan Easygel method for screening purposes and independent testing (e.g. Alabama Water Watch, 1999; Deutsch and Busby, 2000) has shown that Coliscan Easygel results are comparable to standard methods. Polya et al. (2005) found good agreement between arsenic levels 
determined by the Hach kit approach and those determined by IC-ICP-MS at the University of Manchester. Burton and Pitt (2002) also assessed test kit accuracy in evaluating stormwater runoff quality and concluded that test kits can be a useful tool that provide surprisingly accurate results, provided the kits are carefully selected.

Hydrolab Datasonde 4a's were installed at two sites, Russey Keo (Tonle Sap River) and Preak Leap (Mekong River), on 8/16/04, and at two additional sites, Chbar Ampov (Bassac River) and Preak Eng (Mekong River), on 11/16/04 (Figure 24.6). The Hydrolabs record temperature, $\mathrm{pH}$, conductivity, dissolved oxygen, and turbidity, at $15 \mathrm{~min}$. time steps. A field team from RDIC downloads the data and performs routine maintenance on a weekly basis.

Table 24.1 Summary of Buffalo State Manual Sample Locations.

\begin{tabular}{ll}
\hline Site I.D. & \multicolumn{1}{c}{ Site Description } \\
\hline BSC1 & $\begin{array}{l}\text { Open sewer canal immediately upstream of Trabek pumping station } \\
\text { (Trabek Channel) }\end{array}$ \\
BSC2 & Boeng Tumpun treatment wetland \\
BSC3 & Open sewer canal upstream of Tumpun pumping station (Meanchay \\
BSC4 & Channel) \\
BSC5 & Boeng Kak treatment wetland \\
BSC6 & Open sewer canal near Tuol Kork I pumping station \\
& Boeng Cheung Ek treatment wetland \\
\hline
\end{tabular}

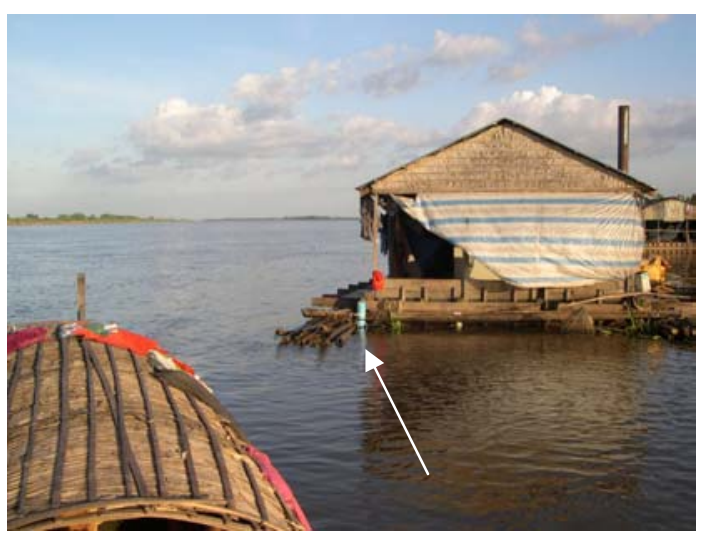

Figure 24.6 Hydrolab installation on floating house, Preak Eng site. 


\subsection{Sampling Program Results}

The levels of $E$. coli, detergents, dissolved oxygen, and nitrate for the six Buffalo State sites (Table 24.1) and the Bassac River from the July/August rainy season sampling are shown in Figure 24.7a-d. The bacteria and detergent levels tended to be higher in the sewer canals (e.g. BSC sites 1, 3, and 5) than in the treatment wetland sites while the dissolved oxygen levels tended to be higher in the treatment wetlands than the sewer sites. There was no clear trend for the nitrate data. The E. coli levels for the Bassac River (see Figure 24.7a) were lower than those reported by Irvine et al. (2006) for earlier sampling (July 2004; January 2005), which were in the 1,100$1,700 / 100 \mathrm{~mL}$ range. Phosphate, nitrate, and dissolved oxygen levels for the Bassac River from the July/August rainy season sampling were similar to those reported by Irvine et al. (2006). At this point, there are not enough data to detect seasonal trends for these analytes.

The levels of $E$. coli, detergents, dissolved oxygen, and phosphate for BSC sites 1, 3, and 6 from both the rainy season and dry season (November $15,2005)$ are shown in Figure 24.8a-d. The E. coli, detergents, and phosphate levels in the sewage at the pumping stations (BSC sites 1 and 3) were higher than the levels in Boeng Cheung Ek while the levels of dissolved oxygen were lower. Again, it appears that the treatment wetland was having a positive impact on water quality. The high levels of detergent in the sewage probably are the result of discharges from numerous factories involved in the garment industry in Phnom Penh.

Samples also were collected at sites 1, 3, and 6 for arsenic analysis during the November sampling, with the levels ranging between 10 and 30 ppb. Irvine et al. (2006) noted that the mean level of arsenic from 1,600 wells in Kandal province was 235 ppb while Agusa et al. (2002) reported an average of $178 \mathrm{ppb}$ for groundwater samples collected at other sites in Kandal province. Polya et al. (2005) found considerable spatial variability in their analysis of 1,072 groundwater arsenic samples from throughout Cambodia. Highest risk areas were from the Holocene sediments near the Mekong and Bassac rivers, with mean arsenic levels of $210 \mathrm{ppb}(\mathrm{n}=401)$ and the maximum level being 1,700 ppb. The Cambodian water standard for drinking water is $50 \mathrm{ppb}$, while the WHO standard is $10 \mathrm{ppb}$. Clearly, sewage would not be used as a drinking water source, but it is possible that the wetlands may be used, after the water is boiled. Boiling will treat biological contamination but will have no effect on arsenic. Although the levels of arsenic in the treatment wetland are not as high as many local 
groundwater sources, the treatment wetlands still should be used with caution. Uptake of arsenic by fish and plants in the wetlands also should be considered as a consumption pathway. The health impacts of arsenic in drinking water have been well documented (e.g. Paul and De, 2000; Safiuddin and Karim, 2003), while Meharg and Rahman (2003) proposed that even with new arsenic-free supplies of water, arsenic in food would continue the disaster in Bangladesh. The soils there have been contaminated by use of arsenic rich groundwater to grow rice in the dry season.

Continuing with the focus on the Boeng Cheung Ek treatment wetland, the mean values of dissolved oxygen, phosphate, $\mathrm{BOD}_{5}$, and total coliform from the monthly Ministry of Environment samples for 2003 and 2004 are shown in Table 24.2. The Stung Chrao site is in the channel that drains the Cheung Ek wetland and discharges to the Bassac River. The Takhmao site is in the Bassac River and downstream of the Stung Chrao discharge.

The mean phosphate, $\mathrm{BOD}_{5}$, and total coliform levels became progressively lower from the Trabek (pump station sewage), to the Stung Chrao, and then the Takhmao sites, while the dissolved oxygen increased. It is worth noting that the dissolved oxygen, $\mathrm{BOD}_{5}$, and phosphate levels shown in Table 24.2 for the Takhmao site are similar to those reported by Irvine et al. (2006) for the Bassac River in 2004 and 2005.

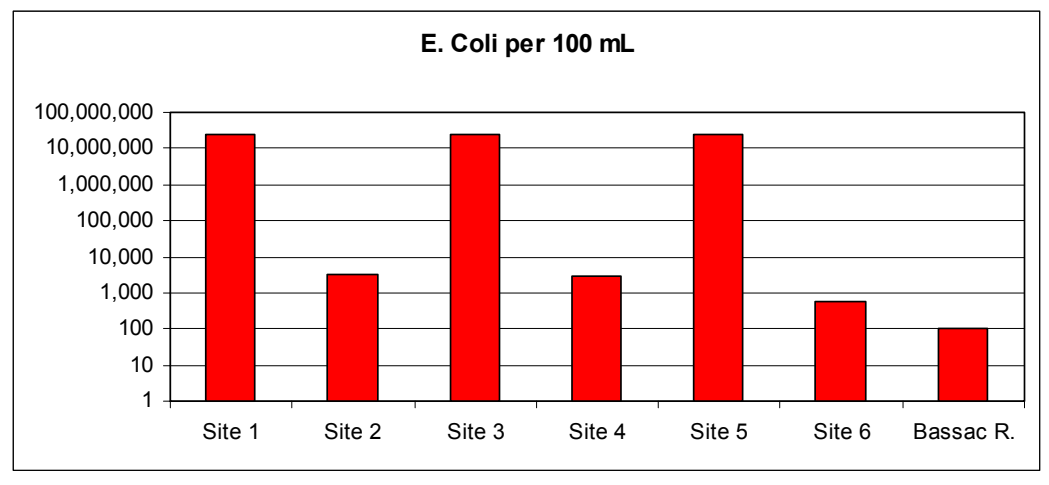

Figure 24.7a July/August sampling results at BSC sites 16 and Bassac River (Figure 24.7b, 24.7c and 24.7d continued on page 483.) 


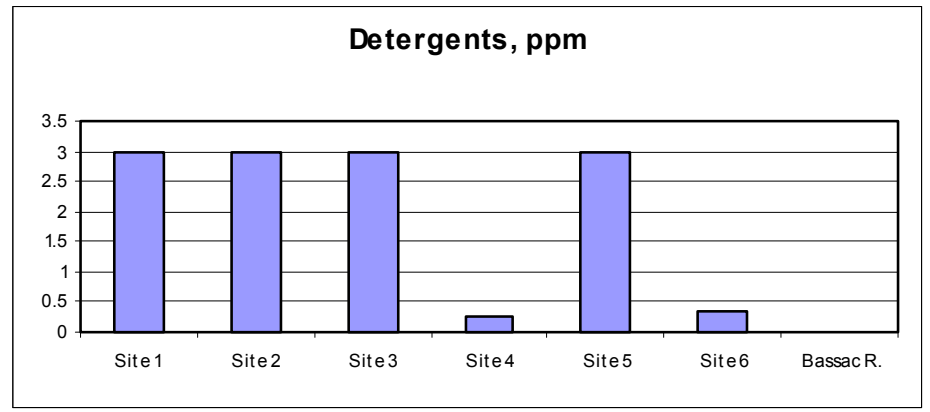

Figure 24.7b Results of the July/August sampling at BSC sites 1 through 6 and the Bassac River (Bassac River value was non-detect; the maximum quantifiable level for this test is $3 \mathrm{ppm}$ and for future testing dilution must be performed).

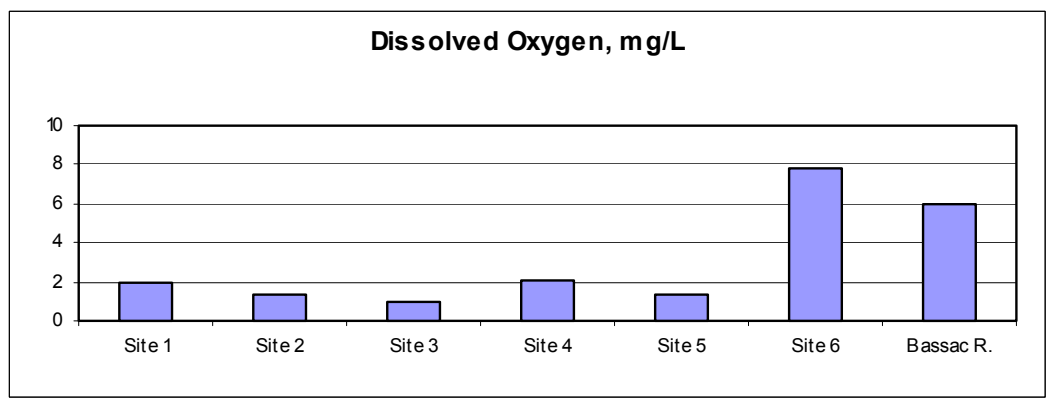

Figure 24.7c Results of the July/August sampling at BSC sites 1 through 6 and the Bassac River.

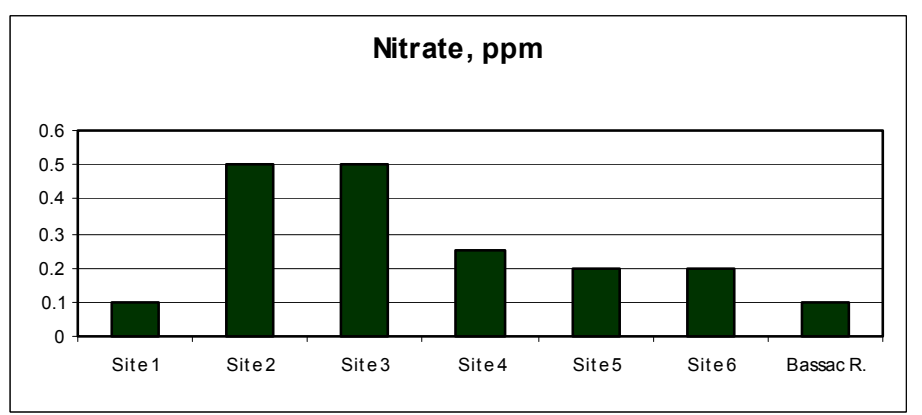

Figure 24.7d Results of the July/August sampling at BSC sites 1 through 6 and the Bassac River. 
Table 24.2 Means and standard deviations (in brackets) of monthly samples, 2003 and 2004.

\begin{tabular}{lcccccc}
\hline Parameter & $\begin{array}{c}\text { Trabek, } \\
2003\end{array}$ & $\begin{array}{c}\text { Stung } \\
\text { Chrao, } \\
2003\end{array}$ & $\begin{array}{c}\text { Takhmao, } \\
2003\end{array}$ & $\begin{array}{c}\text { Trabek, } \\
2004\end{array}$ & $\begin{array}{c}\text { Stung } \\
\text { Chrao, } \\
2004\end{array}$ & $\begin{array}{c}\text { Takhmao, } \\
2004\end{array}$ \\
\hline D.O, mg/L & 1.69 & 5.53 & 5.71 & 2.13 & 4.48 & 5.59 \\
& $(0.65)$ & $(1.17)$ & $(1.12)$ & $(1.17)$ & $(1.10)$ & $(1.59)$ \\
Phosphate, & 3.83 & 1.25 & 0.25 & 10.1 & 3.71 & 0.27 \\
mg/L & $(1.36)$ & $(1.20)$ & $(0.16)$ & $(5.97)$ & $(3.39)$ & $(0.30)$ \\
BOD 5, & 75.6 & 2.97 & 2.01 & 92.8 & 12.1 & 2.44 \\
mg/L & $(26.9)$ & $(1.44)$ & $(1.57)$ & $(18.8)$ & $(9.15)$ & $(0.79)$ \\
Total & 4,204 & 4,097 & 790 & 55,468 & 28,710 & 1,683 \\
Coliform/ & $(6)$ & $(9)$ & $(3)$ & $(11)$ & $(8)$ & $(7)$ \\
$100 \mathrm{~mL}$ & & & & & & \\
\hline
\end{tabular}

Mean for Total Coliform is a geometric mean and standard deviation is geometric standard deviation; all other parameters are arithmetic means and standard deviations; data from Ministry of Environment, Royal Government of Cambodia.

It is possible to show the monthly time series for the different analytes tested by the Ministry of Environment. However, there is variability in the data (because only one sample is taken during the month) and at this stage, it is not possible to visualize seasonal trends. Given the current limitations to the data, examination of average values, as represented in Table 24.2, is appropriate. As more data are collected, it will be possible to conduct more sophisticated analyses.

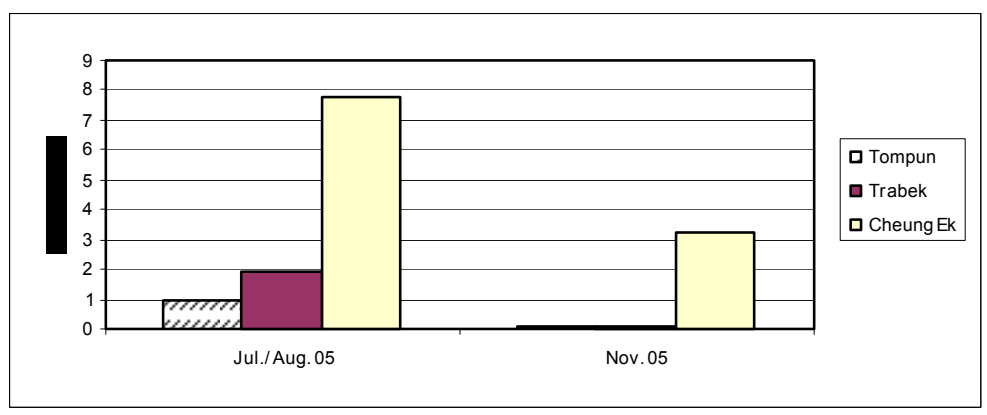

Figure 24.8a Results of July/August, 2005 and November, 2005 sampling at BSC sites 1 (Trabek), 3 (Tompun), and 6 (Cheung Ek). 


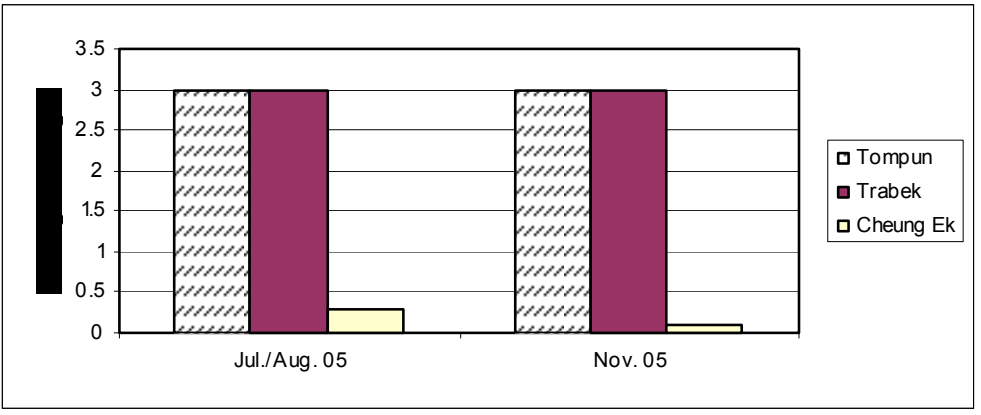

Figure 24.8b Results of July/August, 2005 and November, 2005 sampling at BSC sites 1 (Trabek), 3 (Tompun), and 6 (Cheung Ek).

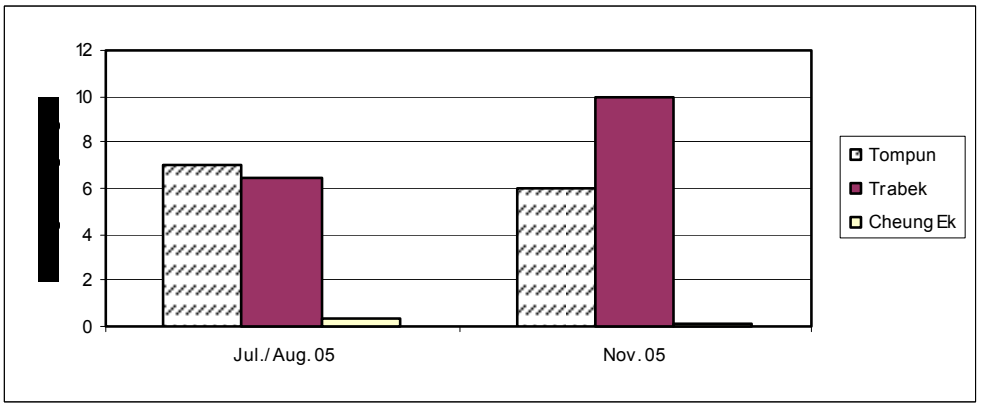

Figure 24.8c Results of July/August, 2005 and November, 2005 sampling at BSC sites 1 (Trabek), 3 (Tompun), and 6 (Cheung Ek).

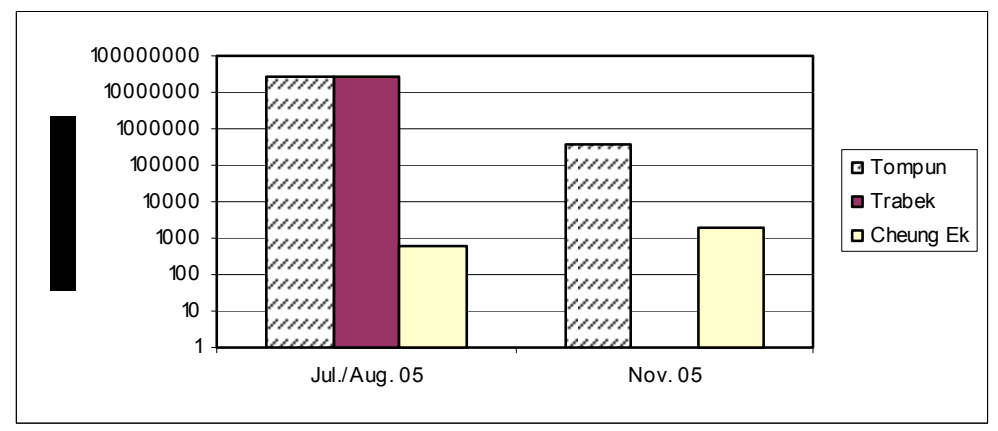

Figure 24.8d Results of July/August, 2005 and November, 2005 sampling at BSC sites 1 (Trabek), 3 (Tompun), and 6 (Cheung Ek). There was no result for the November Trabek sample due to field difficulties. 
Continuous monitoring using Hydrolab datasondes has been shown to provide valuable insights to river system dynamics and the impacts of combined sewer overflows on receiving water quality (e.g. Irvine, 2002; 2003; Irvine et al., 2005; URS Corporation and Buffalo State, 2003; Tomlinson and De Carlo, 2003). Figures 24.9 and 24.10 present weekly mean conductivity and dissolved oxygen levels for the Hydrolab sites on the Phnom Penh waterfront between August, 2004 and May, 2005. Conductivity at the Preak Leap site (upper Mekong River site; see Figure 24.11) began to diverge from the Russey Keo site (Tonle Sap River) in early October and continued this trend until May, at which time conductivity values converged. Conductivity at the Preak Leap site started to diverge at the beginning of the dry season when flow in the main portion of the Mekong River does not mix with the Tonle Sap or Bassac Rivers and this flow phenomenon also can be visualized through satellite imagery (Figure 24.11). In the rainy season (May/June through September) when the monthly mean discharge in the Mekong River can exceed 35,000 $\mathrm{m}^{3} \mathrm{~s}^{-1}$, water from the Mekong flows up the Tonle Sap and down the Bassac rivers (Mekong River Commission, 2005). At this time, conductivity at all Hydrolab sites is similar because of a common source water. The weekly mean dissolved oxygen levels frequently were lower at the Chbar Ampov site (Bassac River), as compared to the other Hydrolab sites, and this would reflect in part the cumulative impacts of waste discharges from Phnom Penh, particularly during the dry season.

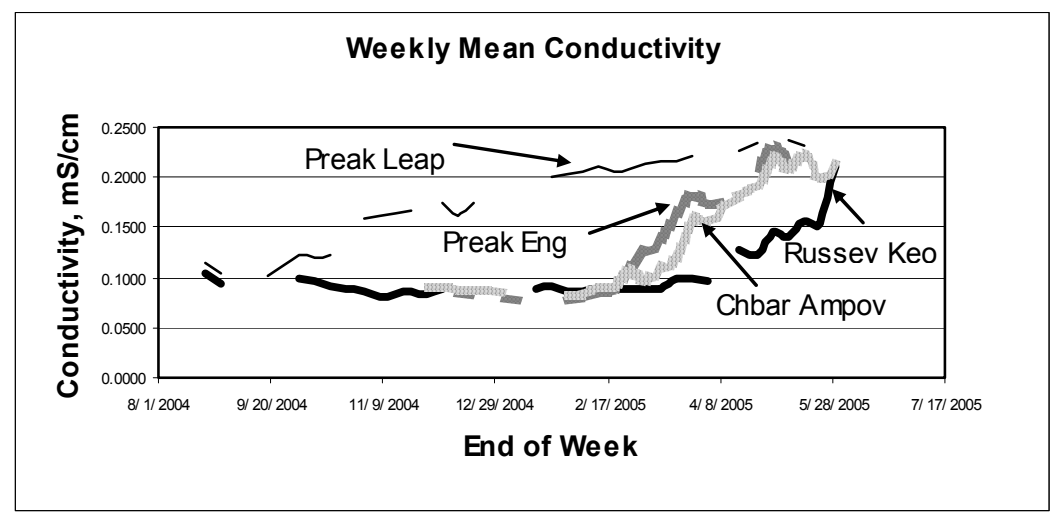

Figure 24.9 Hydrolab results for conductivity. 


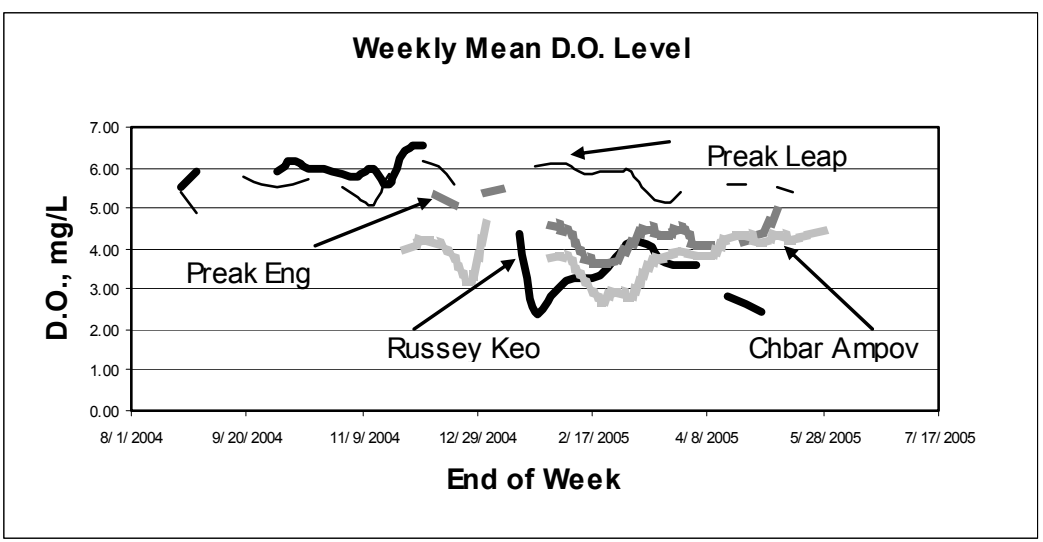

Figure 24.10 Hydrolab results for dissolved oxygen.

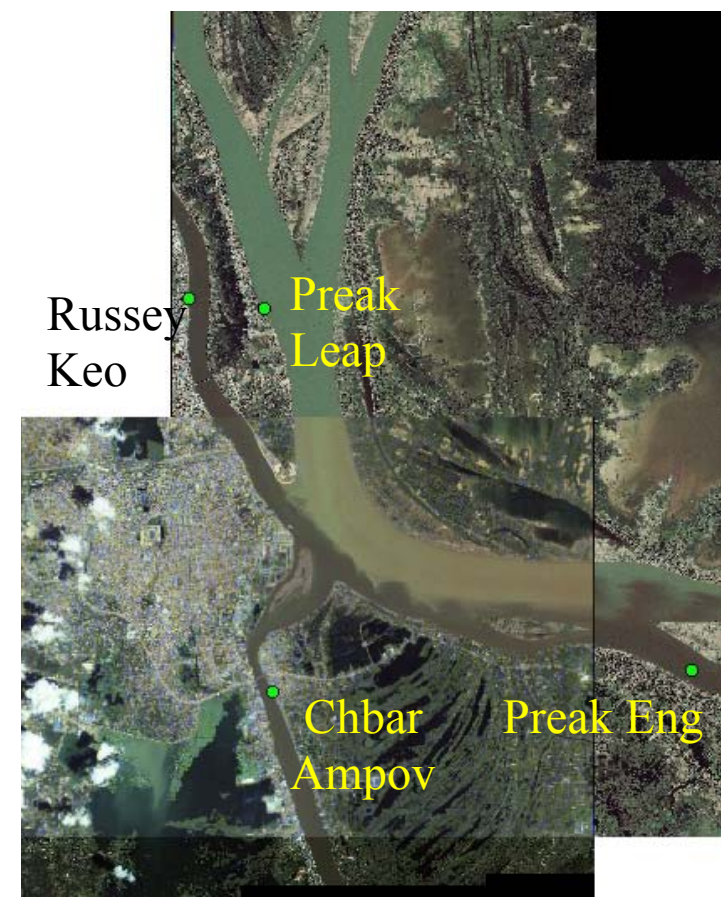

Figure 24.11 Hydrolab sites and flow separation on Mekong River. 


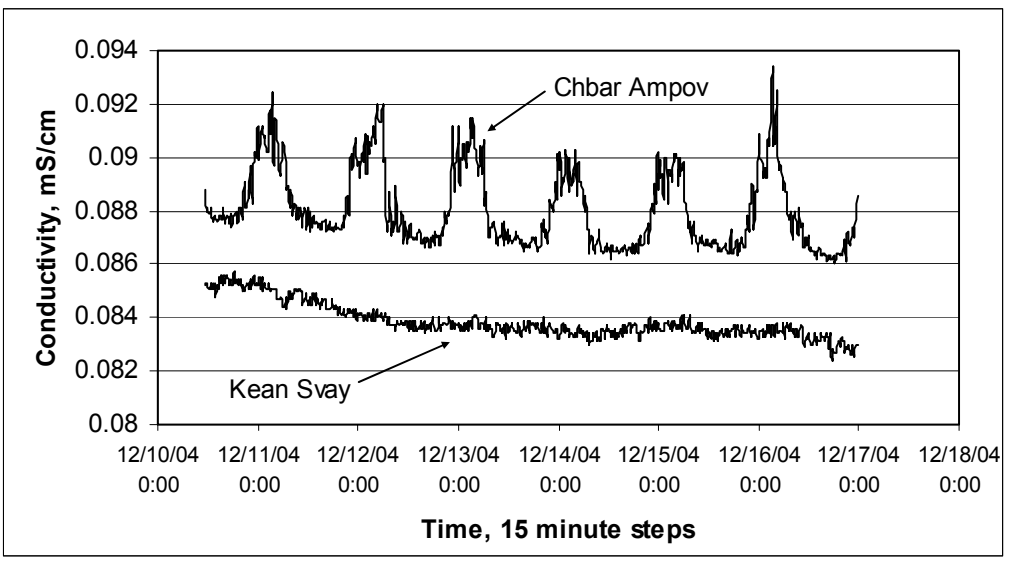

Figure 24.12 Conductivity at Chbar Ampov and Kean Svay (Preak Eng) sites.

\subsection{Model Set-up}

The modeling of the Chaktomuk Junction has a twofold purpose.

1. It is a test area for sediment and erosion modeling. A previous Chaktomuk project has collected useful data which are now supplemented with WUP-FIN measurements for the bank and river bed development analysis. These data are useful in model development and validation.

2. Modeling is justified because of the importance of the junction for a number of issues. For instance upstream and local developments impact analysis on the fish larvae drift to the Tonle Sap is conducted with the model. Scientists are using the model for wastewater and water quality studies. The model can be also used to support bank protection planning and construction.

The model parameters are:

1. flow related physical parameters (3D flow, water depth, flooding)

2. sediment concentration, sedimentation, and bed and bank erosion

3. passive particle tracer indicating transport and dispersion of fish larvae, oil, etc. 
4. passive concentration tracer for wastewater transport and dispersion.

\subsubsection{Grid Specification}

The model covers a $9.55 \mathrm{~km} \times 10.15 \mathrm{~km}$ area around Phnom Penh (Figure 24.13). Four branches are included in the model:

- the Mekong upstream,

- the Tonle Sap River,

- the Bassac River, and

- the Mekong downstream.

The floodplain topography is based on the SRTM DEM. The river channel topography is based on the data collected during the Chaktomuk project. The data have been transformed to the same reference system as the floodplain topography (Ha Thien mean sea level). The basic grid size is $50 \mathrm{~m}$. The number of grid cells in the horizontal plane is $191 \times 203=38,773$. In the vertical there are 10 layers which are $1-2 \mathrm{~m}$ thick to a depth of $12 \mathrm{~m}$. The last layer depth varies according to the total depth. Altogether there are $387,7303 \mathrm{D}$ grid points.

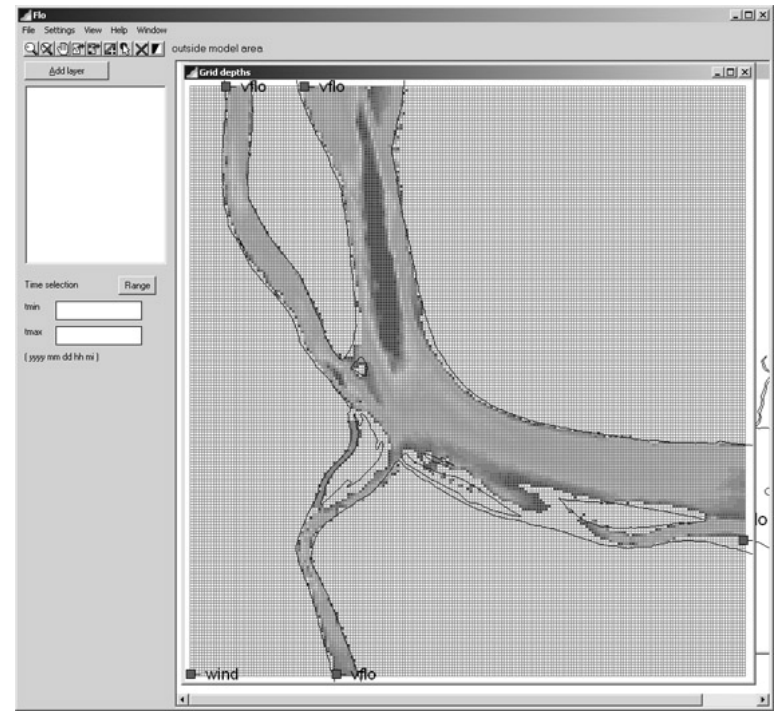

Figure 24.13. Chaktomuk model grid and graphical user interface. 


\subsubsection{Boundary Conditions}

The model boundary data are based on the previous MRCS activities including discharge, water level, and sediment measurements. These data were complemented by the WUP-FIN ADCP measurements during the flood year 2005. The data for the bed and bank erosion modeling were obtained from the ongoing WUP-FIN surveys and the previous Danish Hydraulic Institute Chaktomuk bank erosion study.

\subsection{Model Results}

The EIA 3D model application for Chaktomuk confluence was used to model the impacts of wastewater point load for four periods as specified below:

- Dry Season 10 - 15 April 2002,

- Early Flood 10 - 15 June 2002,

- Peak Flood 10 - 15 September 2002, and

- Receding Flood 10 - 15 October 2002.

Actual data are not available of the wastewater load and thus, a constant load of $10 \mathrm{~kg} / \mathrm{s}$ has been used. This wastewater load can be thought of as a surrogate for a conservative, dissolved-phase contaminant. The model is used to estimate the impacted areas and concentration in those areas.

Two different locations for wastewater point source load have been used, based on the real locations of the discharge points:

- Mekong mainstream, and

- Tonle Sap River

Seven observation points were used in the model to get the simulation results for wastewater concentration: Water supply pumping station, Mekong, Mekong_shore, Ts Point2, Chaktomuk, Phnom Penh Port and TS Point0. Locations of the point sources and observation points are shown in Figure 24.14. 


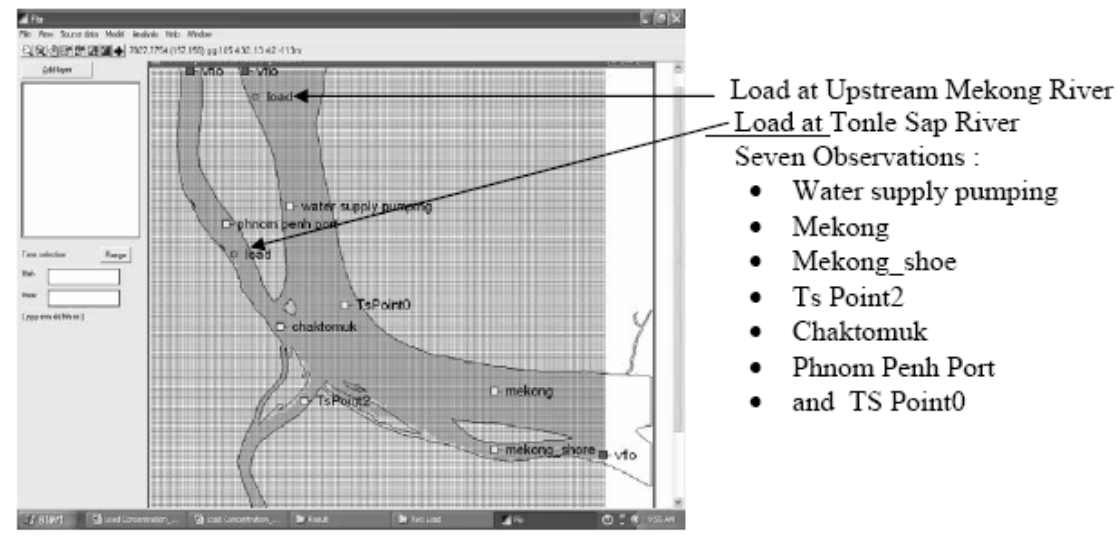

Figure 24.14 Locations of point source load and observation points.

The modeling results are shown below. Different modeling periods are shown for three point source cases:

- Source point in Mekong mainstream (Figure 24.15),

- Source point in Tonle Sap River (Figure 24.16), and

- Source points in Mekong mainstream and Tonle Sap River (Figure 24.17).

The pattern of wastewater dispersal for the dry season where the source point is in the Mekong mainstream (Figure 24.15) visually matches well with the turbidity and flow separation shown in Figure 24.11.

From the model results it can be seen that the impacted areas and concentration of wastewater vary a lot depending on the period of flow regime. The model results show also how the different location of point source impacts on the Chaktomuk confluence region.

Time series results in observation points (Figure 24.14) are presented for the dry season (Figure 24.18) and peak flood (Figure 24.19). The seasonality of the wastewater concentration in these locations can be seen very clearly as well. The concentration at the Water Supply site (Figure 24.18) on the Mekong River is particularly high during the dry season (also see Figure 24.17), while during the peak flood, with the flow reversal up the Tonle Sap River, concentration is high at the Phnom Penh Port (Figure 24.19). 

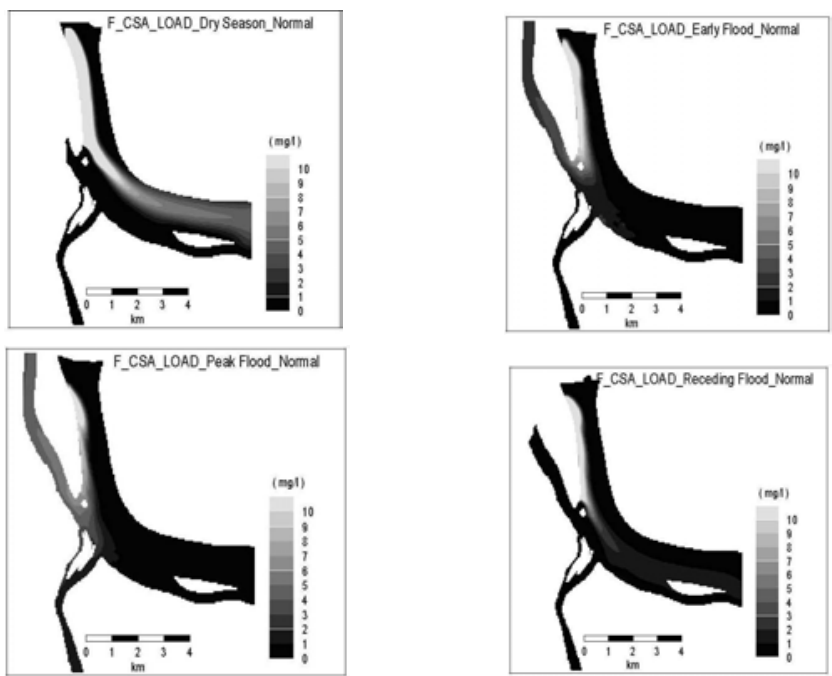

Figure 24.15 Impact of the source point in Mekong mainstream (right bank) during the different modeling periods.
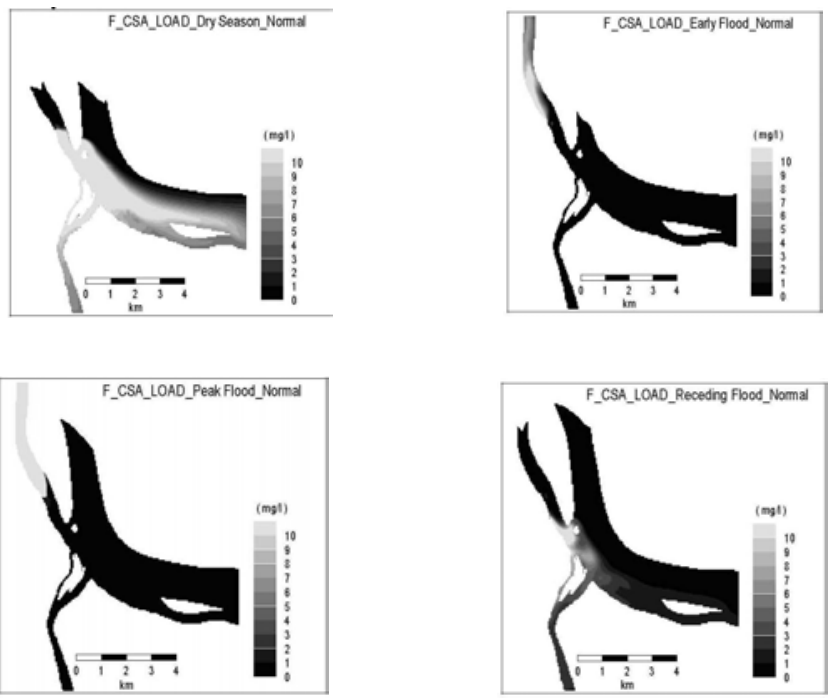

Figure 24.16 Impact of the source point in Tonle Sap River during the different modeling periods. 

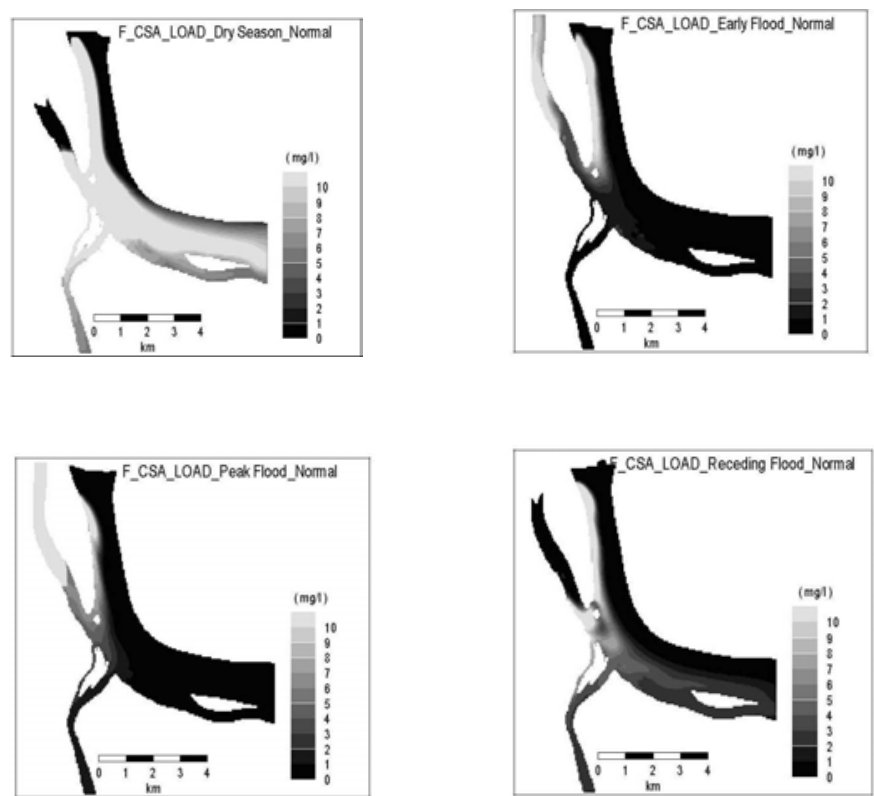

Figure 24.17 Impact of the two source points in Tonle Sap River and Mekong mainstream during the different modeling periods.

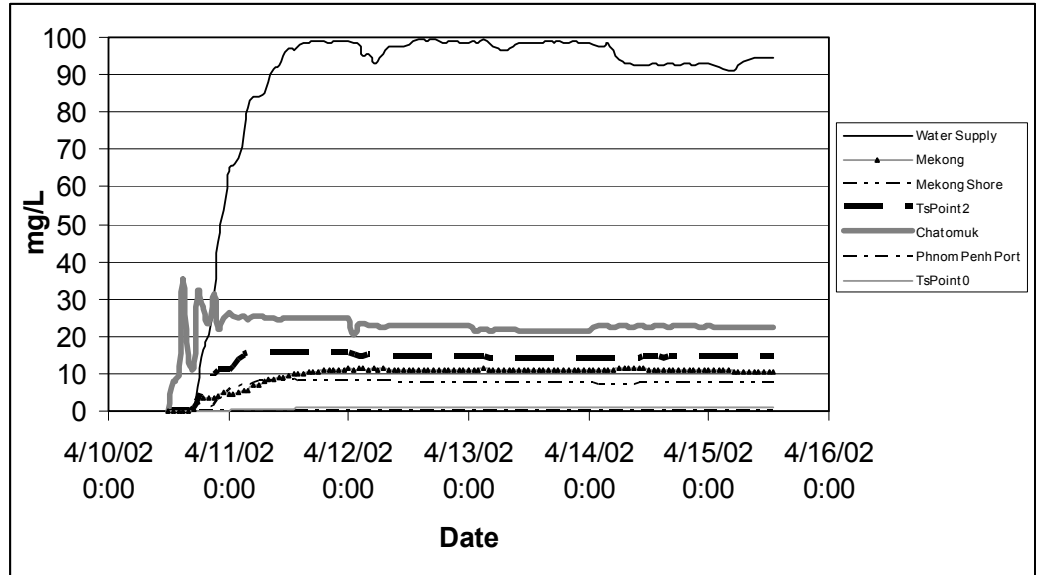

Figure 24.18 Load Concentration in Dry Season (Two Loads at Upstream Mekong River and Tonle Sap River). 


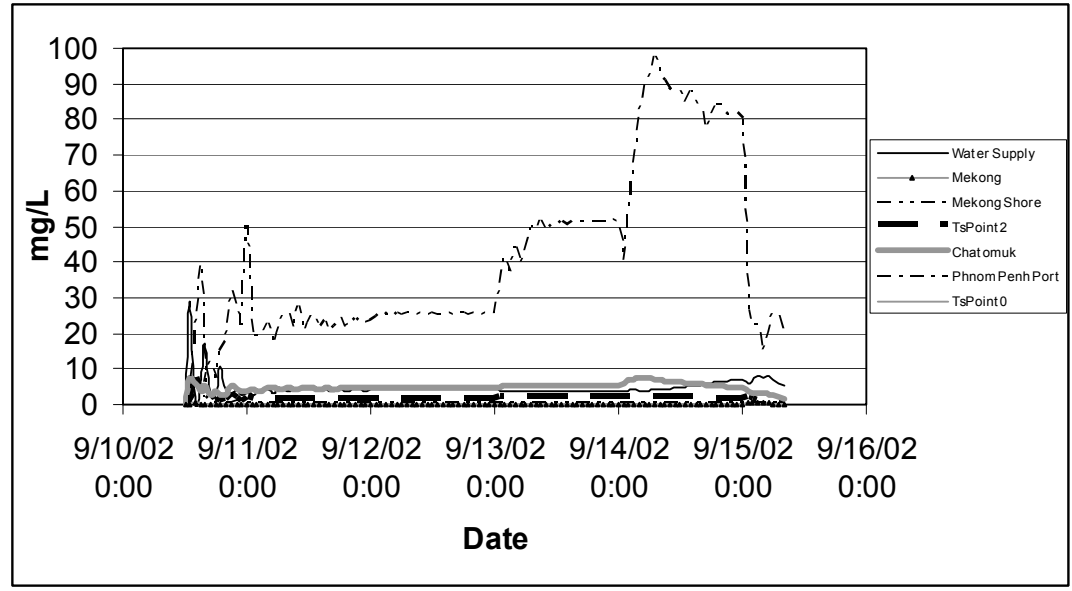

Figure 24.19 Load Concentration in Peak Flood (Two Loads at Upstream Mekong River and Tonle Sap River).

\subsection{Conclusions and Future Tasks}

This chapter describes the initial phase of a cooperative effort to evaluate the efficiency of Phnom Penh's wetlands in treating municipal waste discharge, as well as the impact that all of Phnom Penh's waste discharges have on the Tonle Sap/Mekong/Bassac river system. Funding recently was awarded by the International Foundation for Science (IFS)/Swedish International Development Cooperation Agency (SIDA) and YSI Corporation to further this work. The next phase of the effort will include: a water quality sampling program for the sewer system of south Phnom Penh and the Boeng Cheung Ek wetland; modeling the combined sewage system and wetland using PCSWMM; sampling and analysis of metals in major food stuffs (rice, Morning Glory, fish) to support of human exposure calculations; survey of presence of parasites in the wetlands; evaluation of the health benefits of distributing ceramic filters for drinking water to wetland communities; and a more detailed linkage of the waste load estimates with the EIA 3D model.

This preliminary analysis suggests that the treatment wetlands of Phnom Penh are having some positive impact in reducing contaminant levels from sewage before discharging to the Tonle Sap/Mekong/Bassac system, although treatment efficiency could be improved. Our bacteria results are consistent with those reported by the recent PAPUSSA study. However, 
concerns about bacteria, lead, and arsenic levels in the wetlands water persist. The impact of waste discharges from the city can be identified by the generally lower dissolved oxygen levels and diurnal conductivity patterns in the Bassac River.

The example modeling exercise indicated that impacted areas and concentration of wastewater vary considerably, depending on the period of flow regime. Because of the considerably lower flows in the rivers during the dry season, concentrations were greater, particularly in the Bassac River around Phnom Penh. It will be necessary, through a future sampling program, to confirm the spatial and temporal patterns of waste concentrations suggested by the model. In addition, the program will provide information on specific contaminant classes (e.g. bacteria, nutrients, suspended sediment, metals), rather than the surrogate indicator of waste load.

It is expected that the LMB model will be helpful in assessing the possible transboundary impacts to the Vietnam part of the Mekong Delta. Locally, this work will be most effective as it becomes linked with the Phnom Penh municipality planning sector. One of the steps towards this goal has been the inclusion of the Ministry of Environment personnel in the project. The city of Phnom Penh has increased in population dramatically over the past decade and because of the low elevation of the city, which is susceptible to flooding, there is pressure to infill the treatment wetlands to make way for urban expansion. The municipality will be faced with some important decisions regarding wastewater treatment in the near future.

As our discussion in Section 24.3 indicates, there still is a need to effectively integrate socio-economic, hydrologic, and water quality information for impact assessment and this will be another goal in our next phase of study. Keskinen et al. (2005), for example, used the results of socio-economic surveys (e.g. from available databases and participatory village surveys), topographic zoning in GIS, and results of the 3D EIA model to examine the ecological and socio-economic impacts of drought and floods on rice cultivation and fishing in the Tonle Sap Lake. In our future work we hope to combine information on individual water use (e.g. fishing, drinking, bathing) in the wetlands and along the Mekong/Bassac/Tonle Sap system with contaminant fate modeling to address questions of human health risk. Furthermore, it would be interesting to use an integrative approach to begin to monetarize hydrologic services (e.g. food production; waste treatment) provided by the wetlands in an effort to provide decision support for government and local communities faced with land use change from 
wetland infilling. Sioh et al. (2005) provide some guidance in this type of work.

Finally, we emphasize that training and capacity building is an important element of this work. From sampling, to laboratory analysis, to modeling, Cambodian nationals have significant roles in the project. It is essential to develop the capacity of Cambodians in the multidisciplinary, integrative aspects of this work, so that they will be able to make prudent management decisions in the years to come.

\section{References}

Agusa, T., Kunito, T., Kubota, R., Monirith, I., Tanabe, S., and Tana, T.S. 2002. Arsenic pollution in Cambodia. Biomed. Res. Trace Metals, 13:254-255.

APHA (American Public Health Association), 1985. Standard Methods for the Examination of Water and Wastewater, $16^{\text {th }} \mathrm{ed}$., APHA, Washington, D.C.

Alabama Water Watch, 1999. Quality Assurance Plan for Bacteriological Monitoring. Report for the U.S. Environmental Protection Agency, Region 4.

Browder, G. and Ortolano, L. 2000. The evolution of an international water resources management regime in the Mekong River Basin. Natural Resources Journal, 40:499531.

Burton, G.A. and Pitt, R. A. 2002. Stormwater Effects Handbook: A Toolbox for Watershed Managers, Scientists, and Engineers, Lewis Publishers, Boca Raton, FL.

Campbell, C.S. and Ogden, M. 1999. Constructed Wetlands in the Sustainable Landscape. John Wiley \& Sons, NY.

Dai, J.J., Lorenzato, S., and Rocke, D.M. 2004. A knowledge-based model of watershed assessment for sediment. Environmental Modelling and Software, 19:423-433.

Deutsch, W.G. and Busby, A.L. 2000. A Field and Laboratory Manual for a Communitybased Water Quality Monitoring Program in the Philippines. Report for the Heifer Project International.

Dudgeon, D. 2000. The ecology of tropical Asian rivers and streams in relation to biodiversity conservation. Annu. Rev. Ecol. Syst., 31:239-263.

Fuji, H., Garsdal, H., Ward, P., Ishii, M., Morishita, K. and Boivin, T., 2003. Hydrological roles of the Cambodian floodplain of the Mekong River. International Journal of River Basin Management, 1(3):1-14.

Geoghegan, J., Wainger, L.A., and Bockstael, N.E. 1997. Spatial landscape indices in a hedonic framework: an ecological economic analysis using GIS. Ecological Economics, 23:251-264.

Gugino, H., Irvine, K., Ngern-klun, R., Sukontason, K., Sukontason, K., Prangkio, C., and Thunyapar, P. 2006. Impacts of the urban environment on area source water: the Klong Mae Kha - Chiang Mai, Thailand. Proceedings of the Fourth International Synposium on Southeast Asian Water Environment, Asian Institute of Technology and University of Tokyo. 
Heinonen, U. in press. Do international declarations foster development? In Modern Myths of the Mekong, Helsinki University of Technology and Academy of Finland.

Hiley, P.D. 1995. The reality of sewage treatment using wetlands. Water Science and Technology, 32(3):329-338.

Ingersoll, C.G., MacDonald, D.D., Wang, N., Crane, J.L., Field, L.J., Haverland, P.S., Kemble, N.E., Lindskoog, R.A., Severn, C., and Smorong, D.E. 2000. Prediction of Sediment Toxicity using Consensus-based Freshwater Sediment Quality Guidelines. U.S. EPA Report 905/R-00/007.

Irvine, K. 2002. "Buffalo River Floatables Control and Continuous Water Quality Monitoring Demonstration Project." Journal of Water Management Modeling R208-10. doi: 10.14796/JWMM.R208-10.

Irvine, K.N. 2003. Continuous Measurement of Conventional Parameters in the Allegheny River and Oil Creek, PA, in Support of the Oil City CSO Long Term Control Plan. Report to City of Oil City, PA.

Irvine, K.N., McCorkhill, G., and Caruso, J. 2005. Continuous monitoring of conventional parameters to assess receiving water quality in support of combined sewer overflow abatement plans. Water Environment Research, 77(5):543-552.

Irvine, K., T.P. Murphy, M. Sampson, V. Dany, S. Vermette and T. Tang. 2006. "An Overview of Water Quality Issues in Cambodia." Journal of Water Management Modeling R225-02. doi: 10.14796/JWMM.R225-02.

Islam, S.M.N. 2005. Economic modelling in sustainability science: Issues, methodology, and implications. Environment, Development, and Sustainability, 7:377-400.

JICA (Japan International Cooperation Agency), 1999. The Study on Drainage Improvement and Flood Control, Vol. 2, Municipality of Phnom Penh.

Janssen, W. and Goldsworthy, P., 1996. Multidisciplinary research for natural resource management: Conceptual and practical implications. Agricultural Systems, 51 (3):259-279.

Keskinen, M., Nikula, J., Koponen, J., Sarkkula, J., Kummu, M., and Varis, O. 2005. Integration of socio-economic and hydrological information in the Tonle Sap Lake, Cambodia. In Proceedings of the 2005 International Conference on Simulation and Modeling, V. Kachitvichyanukul, U. Purintrapidan, and P. Utayopas, eds., AIT, Bangkok, pp. 309-318.

Kivaisi, A.K. 2001. The potential for constructed wetlands for wastewater treatment and reuse in developing countries: a review. Ecological Engineering, 16:545-560.

Koponen, J., Kummu, M. and Sarkkula, J., 2005. Modelling environmental change in Tonle Sap Lake, Cambodia.Verh. Internat. Verein. Limnol., 29:1083-1086.

Koottatep, T., Surinkul, N., Polprasert, C., Kamal, A.S.M., Kone, D., Montangero, A., Heinss, U., and Strauss, M. 2005. Treatment of septage in constructed wetlands in tropical climates: Lessons learned from seven years of operation. Water Science and Technology, 51(9):119-126.

Krueger, A.M., Irvine, K.N., Prangkio, C., Chaokasad, K., Sukontason, K., Sukontason, K.L., Ngern-klun, R. 2004. Visualizing water quality trends in Chiang Mai rice paddies: Possible links between environment and health risks. Middle States Geographer, 37:1-8. 
Little, D., Borin, C., Rigg, J. and Dalsgaard, A. 2003. State-of-the-System Report: Cambodia. Production in Aquatic Peri-Urban Systems in Southeast Asia, Report Series No. 2/2003.

Meadows, D.H., Meadows, D.L., Randers, J. and Behrens, W.W. 1972. The Limits to Growth, Signet Books, NY.

Meharg, A.A. and Rahman, M. 2003. Arsenic contamination of Bangladeshi paddy field soils: implications for rice contribution to arsenic consumption. Environmental Science and Technology, 37(2):229-234.

Mesarovic, M., and Pestel, E.1974. Mankind at the Turning Point, Signet Books, NY.

Miller, F. and Hirsch, P. 2003. Civil Society and Internationalized River Basin Management. Working Paper No. 7, Australian Mekong Resource Centre, University of Sydney.

Molyvann, V. 2003. Modern Khmer Cities, Reyum Publishing, Phnom Penh, Cambodia.

MRC, 2003. State of the Basin Report. 50p.

MRC, 2005. Overview of the Hydrology of the Mekong Basin. 73p.

MRC/WUP-FIN, 2005. Inception report, WUP-FIN Phase II - Hydrological, Environmental and Socio-Economic Modelling Tools for the Lower Mekong Basin Impact Assessment. Mekong River Commission and Finnish Environment Institute Consultancy Consortium, Vientiane, Lao PDR. 58 pp.

MRC/WUP-FIN, 2006. Working Paper No.7 - Tonle Sap Lake model application, MRC/WUP-FIN, 2005. Working Paper No.7 - Tonle Sap Lake model application. WUP-FIN Phase II - Hydrological, Environmental and Socio-Economic Modelling Tools for the Lower Mekong Basin Impact Assessment. Mekong River Commission and Finnish Environment Institute Consultancy Consortium, Vientiane, Lao PDR. 65 pp. Available on-line at http://www.eia.fi/wup-fin/wupfin2/publications.htm.

Muong, S. 2004. Avoiding Adverse Health Impacts from Contaminated Vegetables: Options for Three Wetlands in Phnom Penh, Cambodia, Economy and Environment Program for Southeast Asia, Research Report No. 2004-RR5, Singapore.

Nancarrow, B.E., 2005. When the modeller meets the social scientiest or vice-versa. In: A. Zerger and R.M. Argent (Editors), MODSIM05 - International Congress on Modelling and Simulation Advances and Applications for Managements and Decision Making. Melbourne, December 2005.

Nelson, E.A., Specht, W.L., and Knox, A.S. 2004. Metal Removal from Process and Stormwater Discharges by Constructed Treatment Wetlands. Report to U.S. Department of Energy, WSRC-MS-2004-00763.

Paul, B.K. and De, S. 2000. Arsenic poisoning in Bangladesh: a geographic analysis. $J$. Am. Water Res. Assoc.,36(4):799-809.

Phyrun, U. 1996. The environmental situation in Cambodia, policy and instructions. In A. Vlavianos-Arvanitis, ed., Biopolitics, the Bio-Environment, and Bio-Culture in the Next Millennium, Vol. V, Biopolitics International Organization, Athens. 
Polya, D.A., Gault, A.G., Diebe, N., Feldman, P., Rosenboom, J.W., Gilligan, E., Fredericks, D., Milton, A.H., Sampson, M., Rowland, H.A.L., Lythgoe, P.R., Jones, J.C., Middleton, C., and Cooke, D.A. 2005. Arsenic hazard in shallow Cambodian groundwaters. Mineralogical Magazine, 69(5):807-823.

Quinonez-Diaz, M.J., Karpiscak, M.M., Ellman, E.D. and Gerba, C.P. 2001. Removal of pathogenic and indicator microorganisms by a constructed wetland receiving untreated domestic wastewater. J. Environ. Sci. Health A Tox. Hazard Subst. Environ. Eng., 36(7):1311-1320.

Roughley, A. and Salt, D. 2005. Introduction of social sciences in Australian natural resources management agencies. Journal of Research Practice, 1(2):25p.

Safiuddin, M. and Karim, M.M. 2003. Water resources management in the remediation of groundwater arsenic contamination in Bangladesh. In Aquatic Arsenic Toxicity and Treatment, T. Murphy and J. Guo, eds., Backhuys Publishers, The Netherlands, ch. 1.

Sioh, M., Power, J. and Prangkio, C. 2005. Preliminary prototype for a decision support system estimating the economic costs of land use transformation in Northern Thailand. Abstracts, Association of American Geographers Annual General Meeting, Denver, Colorado.

Tomlinson, M.S. and DeCarlo, E.H. 2003. The need for high resolution time series data to characterize Hawaiian streams. J. Am. Water Res. Assoc., 39(1):113-123.

UNEP, 2004. Constructed wetlands: how to combine sewage treatment with phytotechnology. In. Integrated Watershed Management - Ecohydrology \& Phytotechnology, UNEP International Environmental Technology Centre, Japan.

University of Vermont, 2003. Watershed Alliance, Watershed Educator's Handbook.

URS Corporation and Buffalo State, 2003. Hamburg Drain CSO and Buffalo Inner Harbor Water and Sediment Quality - A Preliminary Assessment. Report to the Empire State Development Corporation.

U.S. EPA, 2000. A Handbook of Constructed Wetlands, Volume 2, Domestic Wastewater. U.S. EPA Report, Region III.

Virginia Citizen Water Quality Monitoring Program, 2003. Methods Manual. Report for Virginia Department of Environmental Quality.

Walker, D.J. and Hurl, S. 2002. The reduction of heavy metals in a stormwater wetland. Ecological Engineering, 18: 407-414. 
